\title{
Correction to: AKT-mediated phosphorylation of Sox9 induces Sox10 transcription in a murine model of HER2- positive breast cancer
}

Khalid N. Al-Zahrani ${ }^{1,2}$, John Abou-Hamad ${ }^{1,2}$, Julia Pascoal ${ }^{1}$, Cédrik Labrèche ${ }^{1,2}$, Brennan Garland ${ }^{1,2}$ and Luc A. Sabourin ${ }^{1,2^{*}}$

Correction to: Breast Cancer Res 23, 55 (2021)

https://doi.org/10.1186/s13058-021-01435-6

After publication of the original article [1], the authors identified an error in Figure 2. The correct figure is given below.

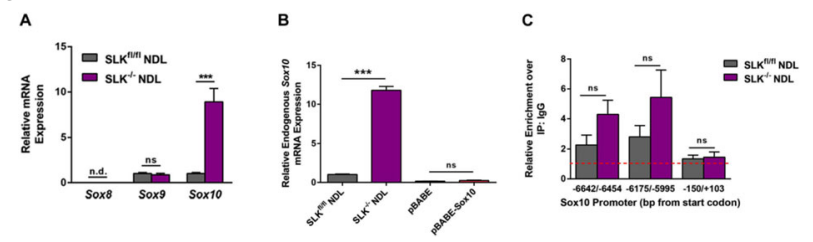

The original article has been corrected.

Published online: 26 May 2021

\section{Reference}

1. Al-Zahrani KN, et al. AKT-mediated phosphorylation of Sox9 induces Sox 10

transcription in a murine model of HER2-positive breast cancer. Breast

Cancer Res. 2021;23:55 https://doi.org/10.1186/s13058-021-01435-6.

\footnotetext{
The original article can be found online at https://doi.org/10.1186/s13058021-01435-6.

*Correspondence: Isabourin@ohri.ca

'Centre for Cancer Therapeutics, Ottawa Hospital Research Institute, 501 Smyth Road, Ottawa, ON K1H 8L6, Canada

${ }^{2}$ Department of Cellular and Molecular Medicine, University of Ottawa,

Ottawa, ON K1H 8M5, Canada
}

(c) The Author(s). 2021 Open Access This article is licensed under a Creative Commons Attribution 4.0 International License, which permits use, sharing, adaptation, distribution and reproduction in any medium or format, as long as you give appropriate credit to the original author(s) and the source, provide a link to the Creative Commons licence, and indicate if changes were made. The images or other third party material in this article are included in the article's Creative Commons licence, unless indicated otherwise in a credit line to the material. If material is not included in the article's Creative Commons licence and your intended use is not permitted by statutory regulation or exceeds the permitted use, you will need to obtain permission directly from the copyright holder. To view a copy of this licence, visit http://creativecommons.org/licenses/by/4.0/ The Creative Commons Public Domain Dedication waiver (http://creativecommons.org/publicdomain/zero/1.0/) applies to the data made available in this article, unless otherwise stated in a credit line to the data. 